\title{
Polymorphism of Lactoferrin Gene with PCR - RFLP and its Association with Subclinical Mastitis in Dairy Cows
}

\author{
Changhong Zhao, Gaoming He (Corresponding author), Yanliang Wang, Zhaoxia Zhang \\ College of Animal Science \& Technology \\ Shihezi University \\ Shihezi 832000, China
}

\begin{abstract}
Incidence of mastitis was checked by the California Mastitis Test (CMT). 120 cows were screened and classified into 2 groups, 60 each group, namely control group (healthy) and experimental group ( subclinical mastitis). Polymorphism of cow lactoferrin gene promoter was determined by polymerase chain reaction-restriction fragment length polymorphism (PCR-RFLP). The results showed that lactorferrin gene promoter was polymorphic among different groups, which indicated that its polymorphism was related to mastitis infection.
\end{abstract}

Keywords: Lactoferrin Gene, RFLP-PCR, Subclinical Mastitis

\section{Introduction}

Lactoferrin in cow milk belongs to the serum transferrin gene family, and is nonhemachrome iron-binding glycoprotein synthesized by glandular epithelial cells and neutrophils (Plaffl, 2003, PP.538-545).Some researches reported (Barkema, 1998, PP.411-419, Hirvoen, 1999, PP.35-46 ) that Lf concentration in milk and serum would change during the infection of mastitis, which indicated that there was some association between Lf and mastitis. Therefore, observation on polymorphism of Lf gene by PCR-RFLP, and association between Lf and mastitis could give some novel insight into theory and practice. In the present paper, polymorphism of Lf gene promoter was investigated by PCR-RFLP, and association between Lf and mastitis was also observed.

\section{Materials and methods}

\subsection{Sampling}

Milk samples collected from a farm in Shihezi, Xinjiang, were detected with CMT reagent, and was primarily classified into two groups, namely control group (healthy) and experimental group (subclinical mastitis), 60 dairy cows each group. Aseptic sampling procedures were undertaken before the start of the project. $10 \mathrm{ml}$ blood samples were collected from the jugular vein of each cow with anticoagulant acid citrate dextrose (ACD) solution, and serum was separated and kept frozen at $-20^{\circ} \mathrm{C}$ for later determinations.

\subsection{DNA extraction}

Genomic DNA was extracted by a sodium dodecyl sulphate method and dissolved in distilled water. The concentration and purity were determined by the optical density method using an Eppendorf

spectrophotometer at 260 and $280 \mathrm{~nm}$. DNA samples were diluted to $50 \mathrm{ng} / \mu \mathrm{l}$ and kept frozen at $-20^{\circ} \mathrm{C}$ until further use.

\subsection{Primer design}

The primers were designed on the basis of DNA sequence of Lf gene promoter accepted by the Genebank (Accession: AY319306) using the oligonucleotide design tool Primer 5.0 software. Forward and reverse primer was 5'-CACATTACAAGCAGGATCTTTTGCTG-3' and 5'-CTGGCCAATGAGCCCTATATGTGT-3', respectively (Shenggong CO.Ltd, Shanghai, China).

\subsection{PCR amplification}

PCR reactions were performed in a $25 \mu \mathrm{l}$ mixture containing $0.7 \mu \mathrm{l}$ forward primers, $0.7 \mu l$ reverse primer, $1.5 \mu \mathrm{l}$ of $2.5 \mathrm{mM}$ dNTP (deoxyribonucleotide triphosphate), $2.5 \mu \mathrm{l} 10 \times$ reaction buffer, $1.5 \mu \mathrm{l}$ of $2.5 \mathrm{mM} \mathrm{MgCl} 2,2 \mu \mathrm{l} 1 \mathrm{unit}$ of Taq-DNA polymerase, and $2.5 \mu \mathrm{l}$ of $50 \mathrm{ng} / \mu \mathrm{l}$ genomic DNA as template. The PCR was performed under the following conditions: $94^{\circ} \mathrm{C}$ for $4 \mathrm{~min}$, followed by 35 cycles of denaturing at $94^{\circ} \mathrm{C}$ for $30 \mathrm{~s}$, annealing at $61^{\circ} \mathrm{Cfor} 45 \mathrm{~s}$, extension at $72^{\circ} \mathrm{C}$ for $45 \mathrm{~s}$; a final extension at $72^{\circ} \mathrm{C}$ for $10 \mathrm{~min}$. PCR products were electrophoretically separated on $0.7 \%$ agarose gel at a constant $75 \mathrm{~V}$, stained with ethidium bromide and excised for sequencing. 


\subsection{Digestion by Hinf I}

Digestion was performed in a $10 \mu \mathrm{l}$ mixture containing $5 \mu$ PCR products, $0.2 \mu 1$ Hinf I, $1 \mu$ l Buffer, $3.8 \mu l$ aseptic double-distilled water. The reaction system was performed under the conditions of $37^{\circ} \mathrm{C}$ for $3 \mathrm{~h}$, and resulting fragments were separated on $8.0 \%$ polyacrylamide gels at a constant $150 \mathrm{~V}$ and detected by silver staining.

\subsection{Data analysis}

Allelic and genotypic frequencies of products after digestion by Hinf I were calculated.

\section{Results and discussion}

\subsection{Amplification of PCR}

Amplification products resulted in a 1143 bp fragment with differences detected by $8.0 \%$ PAGE (polyacrylamide gel electrophoresis) and subsequent silver staining in Lf gene promoter examined in our study (Figure 1).

\subsection{PCR-RFLP results}

Different fragments were separated by PCR products in Lf gene promoter using Hinf I. Among 120 dairy cows detected in this study, 2 allele genes and 3 genotypes were revealed in each group. Allele gene (638bp) was defined as A, whilst allele gene (462bp) as B. Other related genotypes were defined as A/A, A/B and B/B, respectively (Figure 2).

After digestion, allelic and genotypic frequencies were listed in Table 1. As seen in Table 1, Among healthy dairy cows (control group), A/A genotypic frequency was obviously higher than in experimental group. Through $\chi^{2}$-Test, there was great significance between them $(\mathrm{P}<0.01)$; On the contrary, among dairy cows of subclinical mastitis (experimental group), $\mathrm{B} / \mathrm{B}$ genotypic frequency was obviously higher than control group. Through $\chi^{2}$-Test, there was great significance between them $(\mathrm{P}<0.01)$; As for $\mathrm{A} / \mathrm{B}$ genotypic frequency, there was no significance $(\mathrm{P}<0.05)$. In addition, $\mathrm{B}$ allele frequency in experimental group was obviously higher than in control group $(\mathrm{P}<0.01)$ whilst $\mathrm{A}$ allele frequency in control group was obviously higher than in experimental group $(\mathrm{P}<0.01)$.

\section{Conclusions}

Different fragments were obtained in this paper which indicated that there was substitution site mutation in the region of Lf gene promoter.However, in order to confirm effects of such mutation on the expression Lf gene and its association with subclinical mastitis, expression level of Lf gene mRNA and concentration dynamics of Lf in the tissues of dairy cows with subclinical mastitis should still need further investigation.

\section{References}

Barkema, H.W. (1998). Incidence of clinical mastitis in dairy herds grouped in three categories by bulk milk somatic cell counts. J Dairy Sci, 81 (2): 411-419

Plaffl, M.W., Wittmann, S.L., \& Meyerh, H.D., et al. (2003). Gene expression of immunologically important factors in blood cells, milk cells and mammary tissue of cows. J Dairy Sci, 86 (3) : 538-545

Hirvoen, J., Eklund, K., \& Teppo, A.M., et al. (1999). Acute phase response in dairy cows with experimentally induced mastitis. Acta Vet Scand, 40: 35-46

Table 1. Allelic and genotypic frequencies of Lf gene promoter by RFLP

\begin{tabular}{|c|c|c|c|c|c|c|}
\hline \multirow{2}{*}{ Group } & \multirow{2}{*}{$\begin{array}{c}\text { Sample } \\
\text { number }\end{array}$} & \multicolumn{3}{|c|}{ Allelic frequency } & \multicolumn{2}{c|}{ Genotypic frequency } \\
\cline { 3 - 7 } & $\mathrm{A} / \mathrm{A} / \mathrm{B}$ & $\mathrm{B} / \mathrm{B}$ & $\mathrm{A}$ & $\mathrm{B}$ \\
\hline Control group & 60 & $0.5^{* *}$ & 0.4 & 0.1 & $0.78^{* *}$ & $0.22^{* *}$ \\
\hline $\begin{array}{c}\text { Experimental } \\
\text { group }\end{array}$ & 60 & 0.15 & 0.23 & $0.62^{* *}$ & 0.17 & 0.83 \\
\hline
\end{tabular}

Note: ${ }^{* *}, \mathrm{P}<0.01$, great significance 


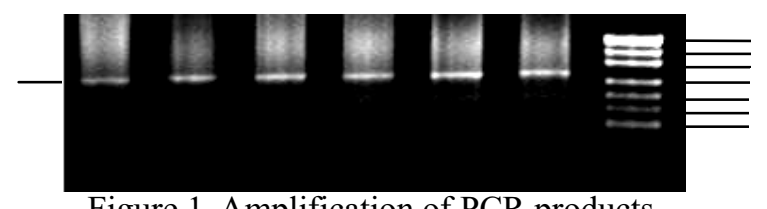

Figure 1. Amplification of PCR products

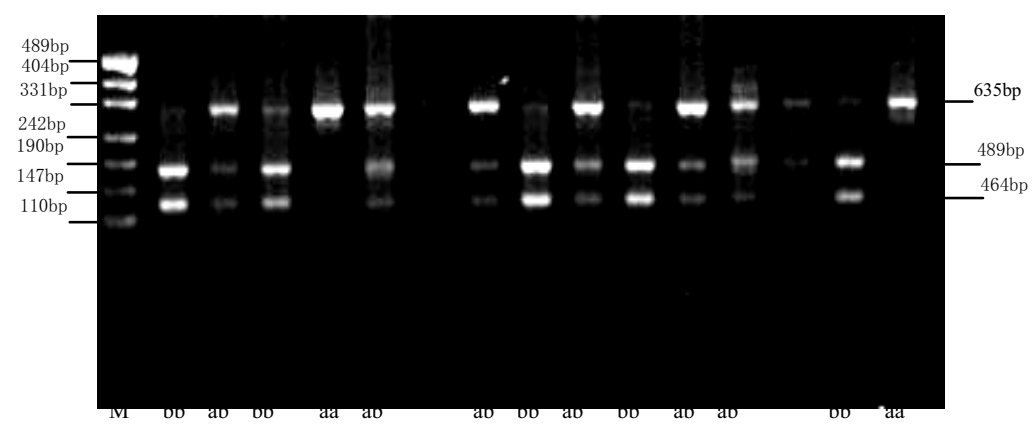

Figure 2. Electrophoresis of digestion with Hinf I in Lf gene promoter 